\title{
Selective Extraction, Preconcentration and Transport Studies of Thorium(IV) Using Octa-Functionalized Calix[4]resorcinarene- Hydroxamic Acid
}

\author{
Vinod K. Jain, ${ }^{\dagger}$ Shibu G. Pillai, Rujul A. Pandya, Yadvendra K. Agrawal, and \\ Pranav S. ShrivaSTAV \\ Department of Chemistry, School of Sciences, Gujarat University, Ahmedabad-380009, India
}

\begin{abstract}
A new calix[4]resorcinarene bearing eight hydroxamic acid groups (C4RAHA) has been synthesized and characterized by FT-IR, ${ }^{1} \mathrm{H}-\mathrm{NMR}$ and elemental analysis. Its analytical properties were investigated, and showed high affinity and selectivity toward thorium(IV) in the presence of large quantities of associated metal ions. Thorium(IV) was extracted from an ethyl acetate solution of C4RAHA at $\mathrm{pH} 4.5$. The $\lambda_{\max }$ and molar absorptivity $(\varepsilon)$ for thorium(IV) were $341 \mathrm{~nm}$ and $71201 \mathrm{~mol}^{-1} \mathrm{~cm}^{-1}$. The complexation of thorium(IV) with C4RAHA has a 4:1 metal:ligand stoichiometry, which is relatively rare. The extracts were directly aspirated in the plasma for ICP-AES measurements for thorium(IV) in the presence of a diversified matrix. The system obeyed Beer's law over the range $0.1-6.5 \mu \mathrm{g} \mathrm{ml}^{-1}$ of thorium(IV) with a Sandell sensitivity of $0.0325 \mu \mathrm{g} \mathrm{cm}-2$. The preconcentration factor and overall stability constant evaluated at $25^{\circ} \mathrm{C}$ for thorium(IV) were 133 and 15.86, respectively. The complexation was characterized by a favorable enthalpy change. A liquid-membrane transport study of thorium(IV) was carried out from the source to the receiving phase under controlled conditions, and a mechanism of transport proposed. To check the validity of the proposed method, thorium(IV) was determined in monazite sand, rare earth sand and water samples.
\end{abstract}

(Received April 30, 2004; Accepted August 23, 2004)

\section{Introduction}

The advent of supramolecular chemistry ${ }^{1}$ and non-covalent interactive forces has made the synthesis and assembling of a wide range of supramolecules increasingly feasible and efficient for metal inclusion. These supramolecular assemblies ${ }^{2}$ possess remarkable structural versatility, and allow an examination of co-operative interaction between the metal centers. Hence, such synthetic supramolecular receptors are in great demand in the extraction and complexation chemistry of large numbers of cationic and anionic species and neutral organic molecules.

Among the different supramolecules, calix[4]resorcinarenes ${ }^{3-6}$ have been widely employed as changeable units with welldefined structures and easy accessibility. Calix[4]resorcinarenes are large cyclic tetramers, and belong to a class of $\left[1_{4}\right]$ metacyclophanes, which have found applications as host molecules, ${ }^{4-10}$ components in liquid crystals, ${ }^{11}$ photoresists, ${ }^{12}$ selective membranes, ${ }^{13}$ surface reforming agents, ${ }^{14}$ HPLC stationary phase, ${ }^{15}$ ion channel mimics,,${ }^{16}$ and metal ion extraction agents. ${ }^{17,18}$

The main source of $\mathrm{Th}(\mathrm{IV})$ is monazite sand, mainly associated with cerium, lanthanum, yttrium, iron, etc. It has found extensive applications in nuclear fuels, used in dissipating static electricity and the gas mantle industry. Thorium(IV) compounds are hazardous, causing environmental pollution. Because of these realities, the processing of nuclear waste before disposal relies most often on solvent-extraction

$\doteqdot$ To whom correspondence should be addressed.

E-mail: drvkjain@ hotmail.com; shibupillai@indiatimes.com procedures, and a large number of extracting agents have been synthesized and tested with the aim of separating Th(IV) more effectively. There are several reagent (thoron-I, arsenazo-III, arsenazo-I, $p$-bromochlorophosphonazo, tribromoarsenazo, etc.) that have been reported for the spectrophotometric determination of $\mathrm{Th}(\mathrm{IV}) .{ }^{19-21}$ The separation of $\mathrm{Th}(\mathrm{IV})$ is done either by liquid-liquid extraction or by solid-phase extraction techniques. A large number of extractants, such as tributylphosphate, trioctyl phosphineoxide, organophosphoric acid, etc., have been reported for the extraction. ${ }^{22-24}$ However, these reagents are either less sensitive, or non-specific, or a large number of diverse ions interfere in their determination. In ion-exchange chromatography, a number of resins have been reported, but they have less specificity, and also low sorption capacities due to the poor loading of metal ions. ${ }^{25-29}$

The macrocycles form the host-guest complex and are used for the complexation of several metal ions; however, complexation with $\mathrm{Th}(\mathrm{IV})$ is scanty. ${ }^{30}$ With this in view, designing a new ligand that can selectively bind Th(IV), one has to overcome a difficult problem, i.e. the ligand must strictly discriminate $\mathrm{Th}(\mathrm{IV})$ from other metal ions present in great excess in monazite sand and other samples. Hydroxamic acids have achieved considerable importance as analytical tools for the separation and determination of a large number of metal ions, including Th(IV). ${ }^{31-35}$

In this communication, we describe the synthesis of octaarmed calix[4]resorcinarene-hydroxamic acid, C4RAHA, and its analytical application for the extraction and simultaneous determination of $\mathrm{Th}(\mathrm{IV})$ in the presence of several interfering ions. The extraction removes the bulk of the major elements and, at the same time, preconcentrates Th(IV) into a small 

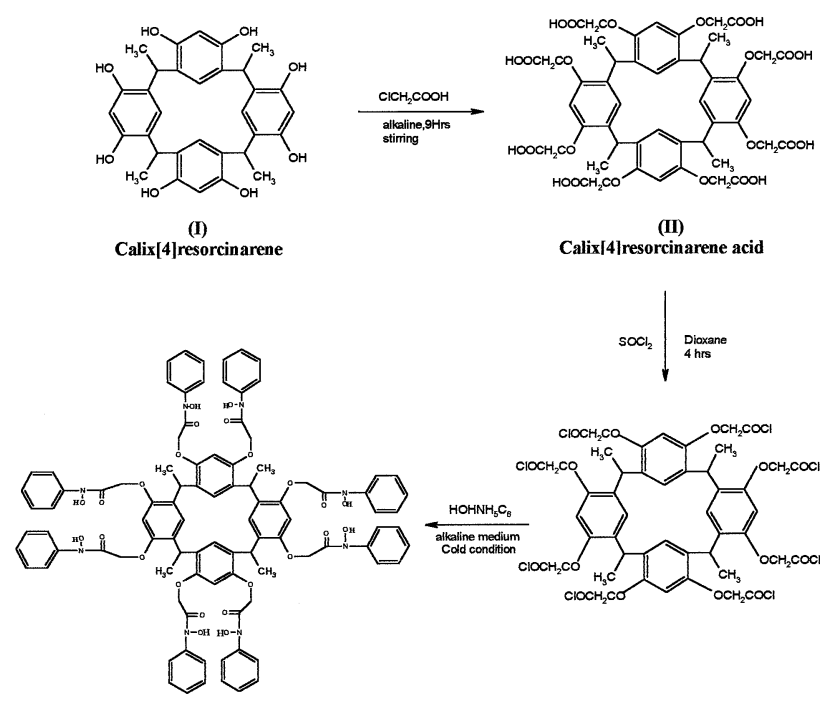

Calix]4|resorcinarene-Hydroxamic acid (C4RAHA)

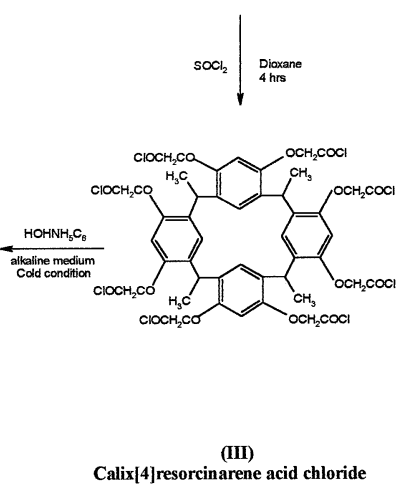

Fig. 1 Synthetic route for calix[4]resorcinarene-hydroxamic acid (C4RAHA).

volume. The extract is directly aspirated into ICP-AES, which increases the sensitivity and detection limit by many fold.

\section{Experimental}

\section{Instruments and measurements}

Electronic spectra were recorded on a Hitachi 3210 UVvisible spectrophotometer with matching $10 \mathrm{~mm}$ quartz cells. A plasma scan Model 710 sequential inductively coupled plasma atomic emission spectrometer along with a plasma scan multitasking computer and peristaltic pump was used. The following operating conditions were set for ICP-AES: Rf, 27.12 $\mathrm{MHz}$; incident power, $2000 \mathrm{~W}$; GMK nebulizer; sample concentration, $1 \mathrm{ppm}$; RF power, $5 \mathrm{~W}$; observation height, 14 $\mathrm{mm}$; argon coolant flow rate, $101 \mathrm{~min}^{-1}$; argon carrier flow rate, $101 \mathrm{~min}^{-1}$; intergraph period, $10 \mathrm{~s}$; resolution, $0.004 \mathrm{~nm}$;

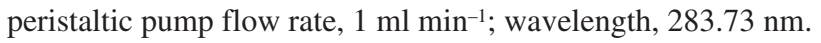

\section{Materials and solutions}

All of the chemicals used were of analytical reagent grade of E. Merck or BDH. All aqueous solutions were prepared with quartz distilled deionized water, which was further purified by a Millipore Milli-Q water purification system. The standard stock solution of thorium(IV) was prepared by dissolving $2.5 \mathrm{~g}$ of thorium nitrate tetrahydrate in $1000 \mathrm{ml}$ of doubly deionized water and standardized spectrophotometrically. ${ }^{36}$ A $0.02 \%(1.2$ $\left.\times 10^{-4} \mathrm{M}\right)$ stock solution of C4RAHA was prepared in ethyl acetate. A working solution was subsequently prepared by appropriate dilution of the stock solution.

Synthesis of calix [4]resorcinarene-hydroxamic acid (C4RAHA)

Calix[4]resorcinarene I was synthesized by the acid-catalyzed condensation of resorcinol and acetaldehyde. ${ }^{3}$ The calix[4]resorcinarene I was functionalized by chloroacetic acid in an alkaline medium to form calix[4]resorcinarene acid II. ${ }^{37,38}$ The calix[4]resorcinarene acid II (10.08 g, $0.01 \mathrm{~mol})$ was refluxed with thionyl chloride $(11.9 \mathrm{~g}, 0.1 \mathrm{~mol})$ in a dioxane medium for $4 \mathrm{~h}$, excess thionyl chloride was distilled, and calix[4]resorcinarene acid chloride III was obtained.

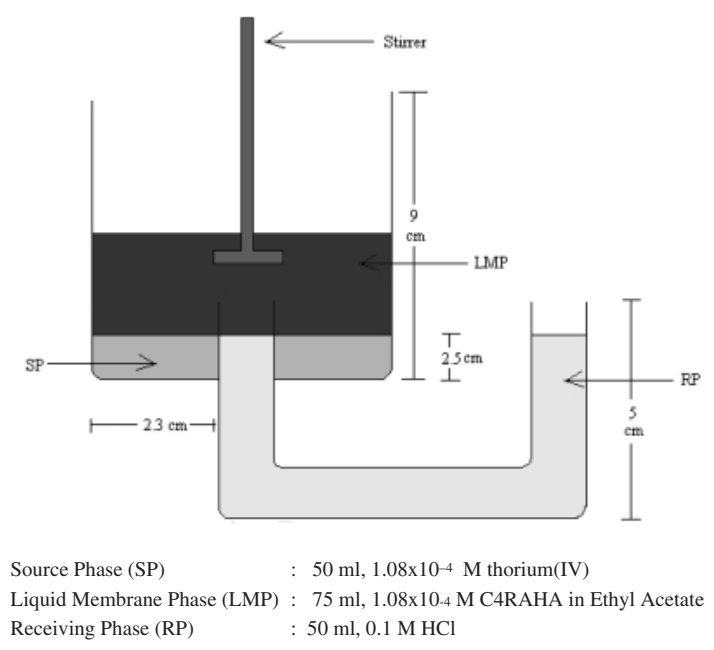

Fig. 2 Apparatus for transport studies.

The calix[4]resorcinarene acid chloride III was added dropwise in a $100 \mathrm{ml}$ conical flask containing an etheral solution of phenyl hydroxylamine and a saturated aqueous solution of sodium bicarbonate. The mixture was stirred continuously for $3 \mathrm{~h}$ at $-5^{\circ} \mathrm{C}$. The reaction mixture was then brought to room temperature and solvent ether was evaporated to obtain the crude product $\mathbf{I V}$, recrystallized from ethyl acetatehexane medium. The yield of IV 55\%, mp $>240^{\circ} \mathrm{C}$ dec.; IR (KBr), 3184, 1622 and $900 \mathrm{~cm}^{-1}$; ${ }^{1} \mathrm{H}$ NMR (DMSO) $\delta 1.65 \mathrm{ppm}$ $\left(\mathrm{d}, \mathrm{CHCH}_{3}\right), \delta 3.4 \mathrm{ppm}(\mathrm{q}, \mathrm{CH}), \delta 4.7 \mathrm{ppm}\left(\mathrm{s}, \mathrm{CH}_{2}\right), \delta 7-8 \mathrm{ppm}$ (s, ArH), $\delta 8.8$ ppm (s, N-OH); Anal. Calcd. for $\mathrm{C}_{96} \mathrm{H}_{88} \mathrm{~N}_{8} \mathrm{O}_{24}: \mathrm{C}$, 66.35; H, 5.10; N, 6.45; O, 22.10. Found: C, 66.43; H, 4.83; N, 6.27, O, 22.47 (Fig. 1).

\section{Liquid-liquid extraction procedure}

An aliquot of a sample solution containing 1.0-65.0 $\mu \mathrm{g}$ of thorium(IV) was transferred into a $25 \mathrm{ml}$ separatory funnel. The $\mathrm{pH}$ of the solution was adjusted to 4.5 for thorium(IV) with the buffer solutions. The mixture was shaken with $3 \mathrm{ml}$ of 1.08 $\times 10^{-4} \mathrm{M}$ C4RAHA in ethyl acetate for 15-18 min. The organic extract was separated, dried over anhydrous sodium sulphate and transferred into a $10 \mathrm{ml}$ volumetric flask. To ensure complete recovery, the extractions were repeated with 1 $\mathrm{ml}$ of C4RAHA. The combined extracts and washings were diluted to the mark with ethyl acetate. The absorbance of the organic phase was measured against the reagent blank at 341 $\mathrm{nm}$. The total concentration of the thorium ion $\left[\mathrm{ThO}^{2+}\right]$ species remaining in the aqueous phase $\left[\mathrm{ThO}^{2+}\right]_{(\mathrm{aq})}$ was measured by ICP-AES.

The concentration of the thorium(IV) extracted into the organic phase, $\left[\mathrm{ThO}_{2}\right]_{(\mathrm{org})}$, as a complex was estimated by $\left[\mathrm{ThO}^{2+}\right]_{(\mathrm{org})}=\left[\mathrm{ThO}^{2+}\right]_{(\mathrm{aq}, \text { initial })}-\left[\mathrm{ThO}^{2+}\right]_{(\mathrm{aq})}$, where $\left[\mathrm{ThO}^{2+}\right]_{(\mathrm{aq}, \text { initial })}$ is the initial concentration of the metal ion in the aqueous phase. The percent extraction $(\% E)$ for thorium(IV) was calculated by

$$
\% E_{\mathrm{Th}}=\left[\mathrm{ThO}^{2+}\right]_{(\mathrm{org})} /\left[\mathrm{ThO}^{2+}\right]_{(\text {aq,initial })} \times 100 .
$$

The extracted C4RAHA-thorium(IV) complex in ethyl acetate after appropriate dilution was also determined by ICP-AES.

\section{Transport of thorium $(I V)$}

The transport of $\mathrm{ThO}^{2+}$ was carried out in a glass assembly, as shown in Fig. 2. The reaction cell was $6.6 \mathrm{~cm}$ in inner diameter 
Table 1 Effect of solvents on the extraction of C4RAHAthorium(IV) complex

\begin{tabular}{lccc}
\hline Solvent & $\begin{array}{c}\text { Dielectric } \\
\text { constant }\end{array}$ & $\begin{array}{c}\text { Extraction, } \\
\%\end{array}$ & $\begin{array}{c}\text { Molar absorptivity/ } \\
1 \mathrm{~mol}^{-1} \mathrm{~cm}^{-1}\end{array}$ \\
\hline Benzene & 2.28 & 11 & $7.83 \times 10^{2}$ \\
Toluene & 2.30 & 36 & $2.56 \times 10^{3}$ \\
Chloroform & 4.80 & 85 & $6.05 \times 10^{3}$ \\
Ethyl acetate & 6.40 & 100 & $7.12 \times 10^{3}$ \\
\hline
\end{tabular}

Thorium(IV), $2.0 \mu \mathrm{g} \mathrm{ml}^{-1}$; C4RAHA, $3.0 \mathrm{ml}, 1.08 \times 10^{-4} \mathrm{M} ; \mathrm{pH}, 4.5$; $\lambda_{\max }, 341 \mathrm{~nm}$.

and $9.0 \mathrm{~cm}$ in height with a total capacity of $305 \mathrm{ml}$. A U-tube (2.0 cm diameter, $20 \mathrm{~cm}$ length) was fused from the base of the cell. The height of the tube inside the cell was $4.0 \mathrm{~cm}$ from the basal plane. The whole assembly was kept in a thermostat maintained at $30^{\circ} \mathrm{C}$. Transport experiments were performed with $50 \mathrm{ml}$ of $1.08 \times 10^{-4} \mathrm{M}$ thorium(IV) solution at $\mathrm{pH} 4.5$ as a source phase, and $50 \mathrm{ml} 0.1 \mathrm{M} \mathrm{HCl}$ as a receiving phase. The liquid membrane consisted of $75 \mathrm{ml}, 1.08 \times 10^{-4} \mathrm{M}$ C4RAHA in ethyl acetate. A synchronous motor (200 rpm) provided constant reproducible stirring from the top. The amount of thorium(IV) transported from the source phase to the receiving phase was measured by ICP-AES. The transport data were the average of 5 runs with an experimental error of less than $2 \%$.

\section{Results and Discussion}

\section{Spectral interpretations}

The structure of IV was characterized by FT-IR and ${ }^{1} \mathrm{H}-\mathrm{NMR}$ spectroscopy and elemental analysis. The IR spectrum showed characteristic absorption at $3184 \mathrm{~cm}^{-1}$ due to $\mathrm{O}-\mathrm{H}$ stretching vibration. It is well known that absorption bands due to $\mathrm{O}-\mathrm{H}$ stretching vibrations, when free, appear at around $3600 \mathrm{~cm}^{-1}$; hydrogen bonding shifts these bands to lower frequencies. ${ }^{39-41}$ In hydroxamic acids, the acidic $\mathrm{O}-\mathrm{H}$ group is placed in a very close proximity of the polar carbonyl group $\mathrm{C}=\mathrm{O}$. The band at $1622 \mathrm{~cm}^{-1}$ is assigned for the $\mathrm{C}=\mathrm{O}$ of the hydroxamic acid group. This assignment is made with respect to the region of amide and anilide. In unsubstituted amide $\mathrm{RCONH}_{2}$, this band is located between 1690 and $1650 \mathrm{~cm}^{-1}$, while in substituted amides RCONHR it is observed at 1680 and $1650 \mathrm{~cm}^{-1}$. The position of the $\mathrm{C}=\mathrm{O}$ stretching band is greatly influenced by the molecular structure, and is generally shifted to lower frequencies. ${ }^{42}$ Thus, hydrogen bonding lowers the $\mathrm{C}=\mathrm{O}$ band by $10-45 \mathrm{~cm}^{-1} .^{42}$ A sharp band at $900 \mathrm{~cm}^{-1}$ is attributed to $\mathrm{N}-\mathrm{O}$ stretching vibration in IV. ${ }^{43-45}$ The ${ }^{1} \mathrm{H}-\mathrm{NMR}$ spectrum of II showed five prominent sharp peaks at 1.6, 3.2, 4.6, 7.6 and 10.2 ppm, which were assigned to methyl, methine, methene, aromatic and carboxylic groups. After phenyl hydroxylamine groups were attached to III, the ${ }^{1} \mathrm{H}$ NMR spectrum of II changed dramatically; a new peak that appeared by the formation of hydroxamic acid groups was observed at 8.8 $\mathrm{ppm},{ }^{46}$ and diminished the carboxylic acid signal, of 10.2 ppm. ${ }^{37,38}$ The results obtained from an elemental analysis of IV confirm the presence of eight hydroxamic acid groups.

\section{Complexation studies and statistical significance}

The complexation of thorium(IV) with C4RAHA was studied under the optimum conditions of the $\mathrm{pH}$, solvent, and reagent (C4RAHA) concentration. Figure 3 shows that the maximum extraction of thorium(IV) was possible in the $\mathrm{pH}$ range of 4.0 -

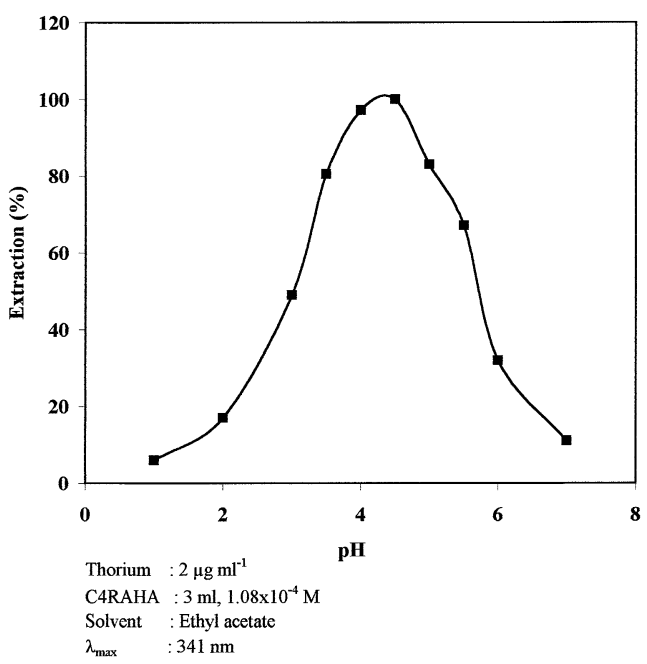

Fig. 3 Effect of the $\mathrm{pH}$ on the extraction of C4RAHA-thorium complex.

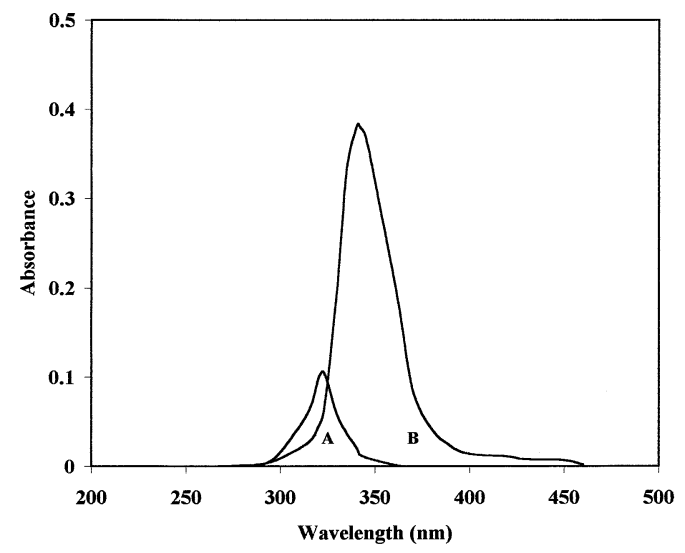

Fig. 4 Comparative spectra of reagent C4RAHA $1.08 \times 10^{-4} \mathrm{M}(\mathrm{A})$ and its thorium complex (B).

4.5; however, above and below this range extraction of the complex were incomplete. It was also found that $15-18 \mathrm{~min}$ of shaking was sufficient for the quantitative extraction of thorium(IV). The extractions were not affected by further shaking, indicating that the equilibrium state had been attained. The effect of a solvent, as shown in Table 1, on the extraction of the C4RAHA-thorium(IV) complex was restricted to ethyl acetate, chloroform, toluene and benzene due its limited solubility in other organic solvents, and it was found that quantitative extraction is possible in ethyl acetate. The spectra of the complex of thorium(IV) showed a bathochromic shift of $18 \mathrm{~nm}$ from that of the reagent C4RAHA in ethyl acetate, as shown in Fig. 4.

Under the optimum conditions, quantitative extraction was possible with $3.0 \mathrm{ml}, 1.08 \times 10^{-4} \mathrm{M} \mathrm{C} 4 \mathrm{RAHA}$ in ethyl acetate. The molar absorptivity measured at the wavelength of the maximum absorption $\left(\lambda_{\max } 341 \mathrm{~nm}\right)$ for the extracted complexes was $71201 \mathrm{~mol}^{-1} \mathrm{~cm}^{-1}$. The system obeyed Beer's law over the range of $0.1-6.5 \mu \mathrm{g} \mathrm{ml}^{-1}$, and the regression analysis equation obtained from the calibrated standard solution of thorium(IV) can be represented as Abs. $=0.153 \times$ Conc. -0.0001645 with a correlation coefficient of $r=0.997$. Sandell's sensitivity, calculated for the proposed method, was $0.0335 \mu \mathrm{g} \mathrm{cm}^{-2}$. The 


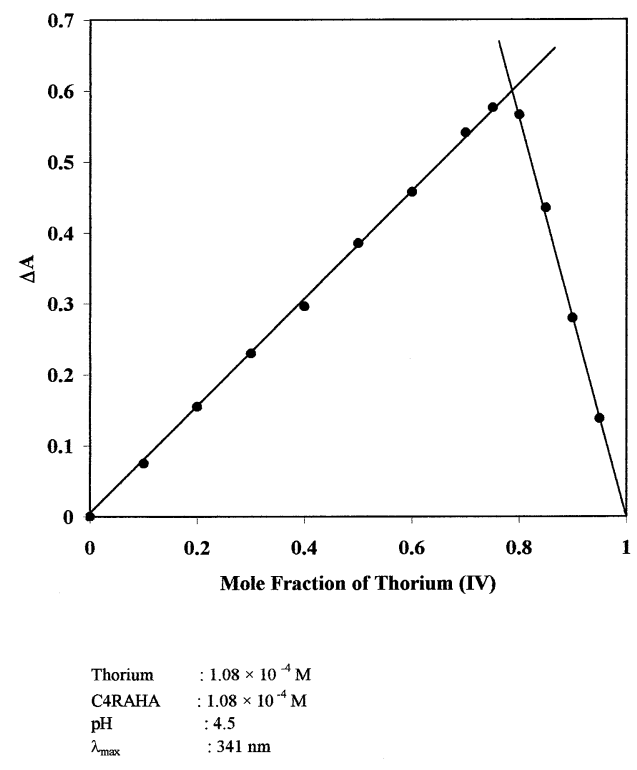

Fig. 5 Stoichiometry of the C4RAHA-thorium(IV) complex.

precision of the proposed method was investigated based on the optimum condition of thorium(IV) extraction, and expressed as a relative standard deviation of $1.9 \%$. The limit of detection (LOD is $3.3 \mathrm{ppb}$ ) was defined as that analyte concentration giving a signal equal to three-times the standard deviation of a blank signal. ${ }^{47}$ The limit of quantification (LOQ is $10.97 \mathrm{ppb}$ ) was then set as ten-times the standard deviation of the blank signal.

\section{Stoichiometry of the complex}

The stoichiometric ratio of the thorium(IV) complex was determined by a modified Job's method of continuous variation. The absorbance of complex $A_{\mathrm{c}}$ of a series of solutions containing thorium ion $\left(\mathrm{ThO}^{2+}\right) a$ and C4RAHA $b$ at a constant total concentration $a+b$, but different concentration ratios, was measured at $341 \mathrm{~nm}$. The absorbance of $b$ was subtracted from the observed absorbance, $A_{c}$, to obtain the difference absorbance $\Delta A$,

$$
\Delta A=A_{\mathrm{c}}-A_{\mathrm{b}} .
$$

The $\Delta A$ values were plotted against the molar ratio of thorium(IV) ion $a /(a+b)$ (Fig. 5). The maximum value for $\Delta A$ was clearly obtained at $a /(a+b)=0.81$, indicating a $4: 1$ stoichiometric ratio of $\mathrm{ThO}^{2+}$ and C4RAHA. The accuracy of this result is possible if only a single complex is formed. To verify this, measurements were taken at different selected wavelengths, which gave the same value for the $a /(a+b)$ ratio.

To obtain more information about the nature of the extracted complex, attempts were made to isolate it from ethyl acetate extract. The extract was evaporated to dryness and subjected to elemental analysis. Further, a known weight of the dry complex was digested with a perchloric and nitric acid mixture. It was centrifuged, and the thorium(IV) content was determined by ICP-AES. The obtained results are in conformity with the complex formulae. The experimental results obtained for the elemental analysis of the C4RAHA-thorium(IV) complex is: carbon, 42.27\%; nitrogen, 4.07\%; hydrogen, 2.97\%; and thorium, $34.11 \%$, which is comparable to their theoretical values: carbon, $42.34 \%$; nitrogen, $4.12 \%$; hydrogen, $2.96 \%$; and thorium, $34.11 \%$.

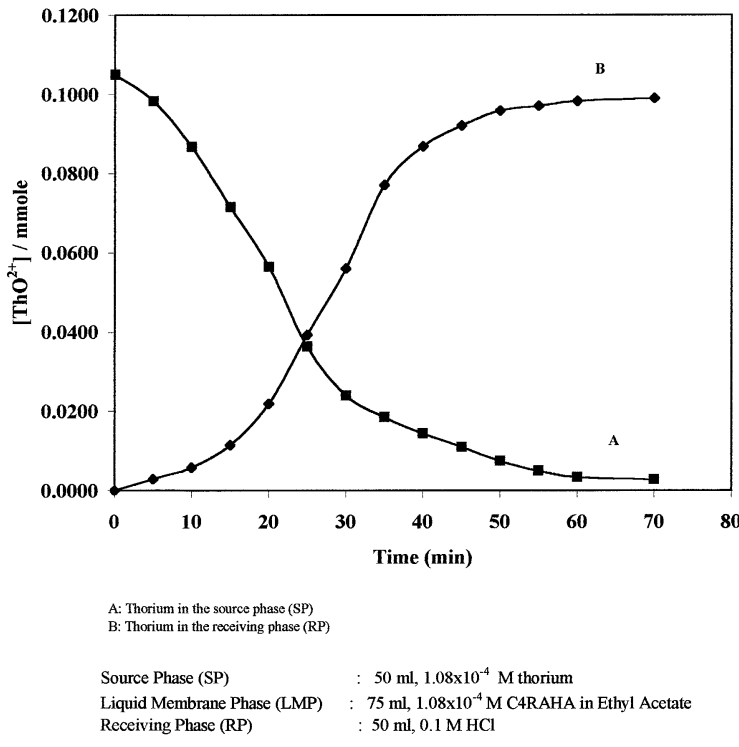

Fig. 6 Transport profile of thorium $\left(\mathrm{ThO}^{2+}\right)$ through a liquid membrane containing C4RAHA at $30^{\circ} \mathrm{C}$.

\section{Extraction studies and equilibria}

To evaluate the binding ability of C4RAHA $\left(\mathrm{H}_{8} \mathrm{~A}\right)$ with thorium(IV), a liquid-liquid extraction (water-ethyl acetate system) was carried out, and the extraction constants were determined.

The extraction equilibria for thorium(IV) can be expressed by

$$
4 \mathrm{ThO}^{2+}{ }_{(\mathrm{a})}+\mathrm{H}_{8} \mathrm{~A}_{(\mathrm{o})} \rightleftharpoons\left[\left(\mathrm{ThO}^{2+}\right)_{4} \mathrm{~A}^{8-}\right]_{(\mathrm{o})}+8\left[\mathrm{H}^{+}\right]_{(\mathrm{a})},
$$

where the species in the organic and aqueous phases are denoted by subscripts (o) and (a), respectively.

The extraction constant, $K_{\mathrm{ex}}$, is given by

$$
K_{\mathrm{ex}}=\frac{\left[\left(\mathrm{ThO}^{2+}\right)_{4} \mathrm{~A}^{8-}\right]_{(\mathrm{o})}+\left[\mathrm{H}^{+}\right]_{(\mathrm{a})}^{8}}{\left[\mathrm{ThO}^{2+}\right]_{(\mathrm{a})}^{4}\left[\mathrm{H}_{8} \mathrm{~A}\right]_{(\mathrm{o})}} .
$$

Also, the distribution ratio of thorium(IV) in the two phases can be given by

$$
D=\frac{\left[\left(\mathrm{ThO}^{2+}\right)_{4} \mathrm{~A}^{8-}\right]_{(\mathrm{O})}}{\left[\mathrm{ThO}^{2+}\right]_{(\mathrm{a})}^{4}} .
$$

From Eqs. (2) and (3), we obtain

$$
K_{\mathrm{ex}}=\frac{D\left[\mathrm{H}^{+}\right]_{(\mathrm{a})}^{8}}{\left[\mathrm{H}_{8} \mathrm{~A}\right]_{(\mathrm{o})}} .
$$

Equation (4), can be written as

$$
\log K_{\text {ex }}=\log D+8 \log \left[\mathrm{H}^{+}\right]-\log \left[\mathrm{H}_{8} \mathrm{~A}\right] .
$$

The extraction constant, $K_{\mathrm{ex}}$, may be obtained from the above Eq. (5), where

$$
\left[\mathrm{H}_{8} \mathrm{~A}\right]=\frac{\left(C_{\mathrm{H}_{8}} \cdot P_{\mathrm{H}_{8} \mathrm{~A}}\right)}{1+P_{\mathrm{H}_{8} \mathrm{~A}}+\left(k_{\mathrm{a}} /\left[\mathrm{H}^{+}\right]\right)} .
$$

In this expression, $C_{\mathrm{H}_{8} \mathrm{~A}}$ is the analytical concentration of the reagent, $\mathrm{H}_{8} \mathrm{~A} ; P_{\mathrm{H}_{8} \mathrm{~A}}$ and $k_{\mathrm{a}}$ are its respective distribution constant 
Table 2 Stability constant and thermodynamic parameters for the C4RAHA-thorium(IV) complex

\begin{tabular}{cccccccc}
\hline Temp./K & $\mathrm{p} K_{\mathrm{a}}$ of $\mathrm{H}_{8} \mathrm{~A}$ & $\log P_{\mathrm{H}_{8} \mathrm{~A}}$ & $\log \beta_{4} \cdot \mathrm{P}_{\mathrm{Th}-\mathrm{H}_{8} \mathrm{~A}}$ & $\log K_{\text {ex }}$ & $\Delta G / \mathrm{kJ} \mathrm{mol}^{-1}$ & $\Delta H^{\mathrm{a}} / \mathrm{kJ} \mathrm{mol}^{-1}$ & $\Delta S / \mathrm{kJ}^{-1} \mathrm{~mol}^{-1}$ \\
\hline 298 & 8.90 & 23.00 & 15.86 & $9.12 \times 10^{-17}$ & -90.41 & - & -391.37 \\
303 & 8.85 & 23.05 & 16.45 & $3.55 \times 10^{-16}$ & -95.35 & -203.82 & -368.61 \\
308 & 8.74 & 23.16 & 17.03 & $1.35 \times 10^{-15}$ & -100.34 & -207.09 & -346.42 \\
313 & 8.65 & 23.25 & 17.59 & $4.90 \times 10^{-15}$ & -105.32 & -206.55 & -324.97 \\
318 & 8.57 & 23.33 & 18.14 & $1.74 \times 10^{-14}$ & -110.35 & -209.45 & -304.40 \\
323 & 8.51 & 23.39 & 18.67 & $5.88 \times 10^{-14}$ & -115.36 & -208.28 & -283.83 \\
\hline
\end{tabular}

a. Mean $\Delta H=-207.038 \mathrm{~kJ} \mathrm{~mol}^{-1}$.

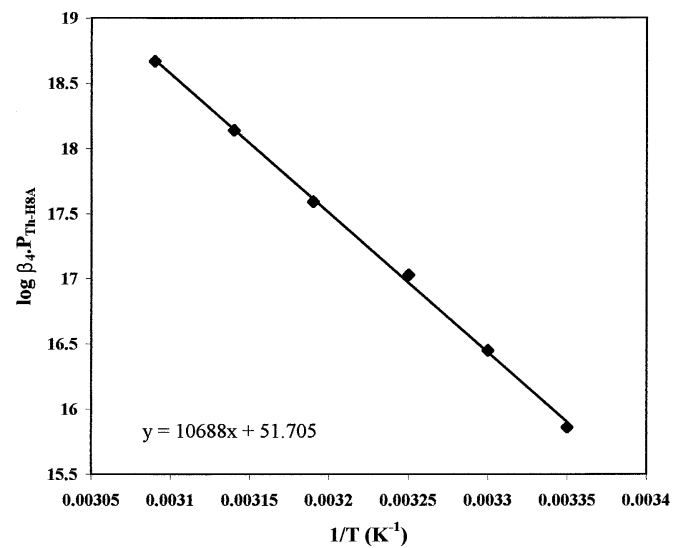

Fig. 7 Variation of the two-phase stability constant with the temperature $\left(T^{-1}\right)$.

and acid dissociation constant. With the aid of Eq. (6) and the values of $\mathrm{p} K_{\mathrm{a}}=8.9$ and $\log P_{\mathrm{H}_{8} \mathrm{~A}}$, the $K_{\mathrm{ex}}$ values were calculated by a least-squares procedure. Also, the two-phase stability constant $\left(\log \beta_{4} \cdot P_{\mathrm{Th}-\mathrm{H}_{8} \mathrm{~A}}\right)$ was obtained from the relation

$$
\log \beta_{4} \cdot P_{\mathrm{Th}-\mathrm{H}_{8} \mathrm{~A}}=\log K_{\mathrm{ex}}+\mathrm{p} K_{\mathrm{a}}+\log P_{\mathrm{H}_{8} \mathrm{~A}},
$$

where $\beta_{4}$ and $P_{\mathrm{Th}-\mathrm{H}_{\mathrm{H}} \mathrm{A}}$ are the respective overall formation constant and the distribution constant of the $\left[\left(\mathrm{ThO}^{2+}\right)_{4} \mathrm{~A}^{8-}\right]$ complex in the two phases. Table 2 summarizes the value of $\log \beta_{4} \cdot P_{\mathrm{Th}-\mathrm{H}_{8} \mathrm{~A}}$ and $\log K_{\mathrm{ex}}$ at different temperatures.

\section{Liquid membrane transport studies}

Considerable effort has been directed over the last two decades to the transport of metal ions across a liquid membrane ${ }^{48}$ A liquid membrane is a liquid phase, which separates two other liquid phases with which it is immiscible. These liquid membranes are of interest both for possible technological applications and for fundamental studies of the transport process. The transport of $\left[\mathrm{ThO}^{2+}\right]$ through a membrane containing $1.08 \times 10^{-4} \mathrm{M}$ C4RAHA from the source phase of $\left[\mathrm{ThO}^{2+}\right]=1.08 \times 10^{-4} \mathrm{M}$ to the receiving phase of 0.1 $\mathrm{M} \mathrm{HCl}$ was carried out. As evident from Fig. 6, the concentration of $\mathrm{ThO}^{2+}$ in the source phase started to decrease continuously, and reached a lower concentration than the detection limit after $22 \mathrm{~min}$ (curve A). On the other hand, the concentration of $\mathrm{ThO}^{2+}$ in the receiving phase incurred, as shown in the curve $\mathrm{B}$. Therefore, it is clear that $\mathrm{ThO}^{2+}$ moved from the source to receiving phase through the liquid membrane. The carrier in the membrane reacted with $\mathrm{ThO}^{2+}$ in the source phase at the interface of these phases, and formed a complex $\left[\left(\mathrm{ThO}^{2+}\right)_{4} \mathrm{~A}^{8-}\right]$ while releasing 8 moles of proton into the source phase. At the other interface of the membrane and

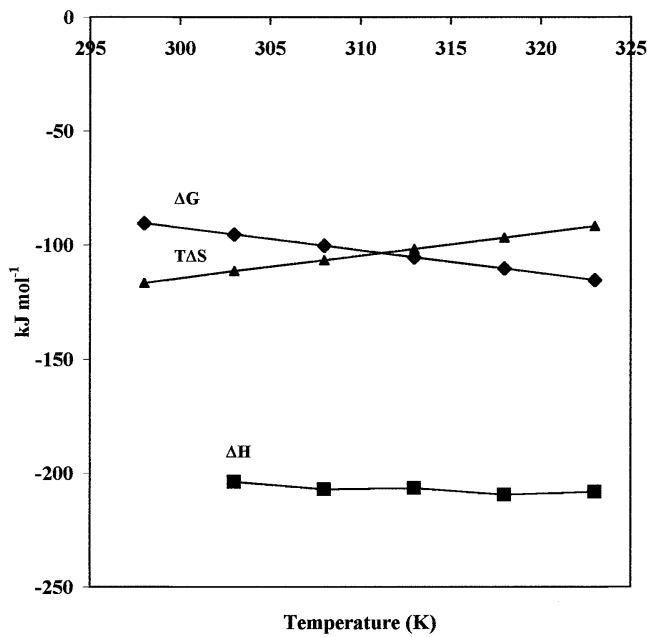

Fig. 8 Variation in the thermodynamic parameter with temperature.

the receiving phase, the complex reacted with 8 moles of protons while releasing 4 moles of $\mathrm{ThO}^{2+}$ in the receiving phase.

\section{Effect of the temperature and thermodynamic parameters}

The extractions of thorium(IV) from aqueous solution were studied at different temperatures between $298 \mathrm{~K}$ and $323 \mathrm{~K}$; the results show that the extraction equilibrium constant $\left(\log K_{\text {ex }}\right)$ and two-phase stability constants for thorium(IV) $\left(\log \beta 4 \cdot P_{\text {Th- } \mathrm{H}_{8} \mathrm{~A}}\right)$ increased with an increase in temperature (Table 2). The change in the extraction equilibrium constant ( $\ln K_{\mathrm{ex}}$ ) with temperature can be expressed by the Van't Hoff equation,

$$
\mathrm{d}\left(\ln \left(K_{\mathrm{ex}}\right)\right) / \mathrm{d} T=\Delta H^{0} / R T^{2} .
$$

In order to utilize this equation for calculations, it must be integrated while assuming that the heat of reaction $(\Delta H)$ remains constant over a small range of temperature,

$$
\ln \left(K_{\mathrm{ex}}\right)=-\Delta H^{0} / R T+\text { constant }(\text { intercept }) .
$$

Plots of $\left(\log \beta_{4} \cdot P_{\mathrm{Th}-\mathrm{H}_{8} \mathrm{~A}}\right)$ against $1 / T$ yield a straight-line equation, $10688 x+51.705$, with slope $(x)-\Delta H^{0} / 2.303 R$ (Fig. 7). The enthalpy change accompanying complexation was found to be $-207.038 \mathrm{~kJ} \mathrm{~mol}^{-1}$ in the given range of temperatures. An inspection of Fig. $8\left(\Delta H^{0},-T \Delta S^{0}, \Delta G^{0} \rightarrow T\right)$ reveals that the complexation is driven by a favorable enthalpy change. The negative values of the free energy suggest that the reaction is exothermic and favorable for complexation.

\section{Effect of diverse ions}

The extraction of a single metal ion under controlled condition 
Table 3 Effect of diverse ions on the extraction of C4RAHAthorium(IV) complex

\begin{tabular}{cccc}
\hline \multirow{2}{*}{ Ion } & \multirow{2}{*}{$\begin{array}{c}\text { Amount } \\
\text { added/mg }\end{array}$} & \multicolumn{2}{c}{ Recovery of thorium(IV)/ppm } \\
\cline { 3 - 4 } & & Spectrophotometry & ICP-AES \\
\hline $\mathrm{Ag}^{+}$ & 40 & 9.9 & 9.99 \\
$\mathrm{Be}^{2+}$ & 40 & 10.1 & 9.99 \\
$\mathrm{~Pb}^{2+}$ & 45 & 9.8 & 9.98 \\
$\mathrm{Mn}^{2+}$ & 40 & 9.9 & 9.99 \\
$\mathrm{Ni}^{2+}$ & 60 & 9.9 & 10.03 \\
$\mathrm{Cu}^{2+}$ & 50 & 10.2 & 10.01 \\
$\mathrm{Zn}^{2+}$ & 45 & 10.1 & 9.99 \\
$\mathrm{Cd}^{2+}$ & 40 & 9.8 & 9.98 \\
$\mathrm{Hg}^{2+}$ & 50 & 10.0 & 9.99 \\
$\mathrm{Pd}^{2+}$ & 40 & 9.7 & 9.99 \\
$\mathrm{Al}^{3+}$ & 50 & 9.8 & 10.02 \\
$\mathrm{Sn}^{2+}$ & 40 & 9.9 & 9.97 \\
$\mathrm{La}^{3+}$ & 50 & 10.2 & 9.99 \\
$\mathrm{Ce}^{4+}$ & 50 & 10.1 & 9.97 \\
$\mathrm{Zr}^{4+}$ & 50 & 9.8 & 9.99 \\
$\mathrm{Mo}^{6+}$ & 50 & 9.7 & 9.99 \\
$\mathrm{UO}_{2}{ }^{2+}$ & 50 & 10.2 & 10.00 \\
$\mathrm{~V}^{5+}$ & 50 & 10.3 & 10.00 \\
$\mathrm{Fe}^{2+}$ & 45 & 9.96 & 10.00 \\
$\mathrm{Cr}^{3+}$ & 40 & 9.9 & 10.00 \\
$\mathrm{Mg}^{2+}$ & 60 & 9.9 & 10.00 \\
\hline
\end{tabular}

Thorium(IV), $10.0 \mu \mathrm{g} \mathrm{ml}^{-1}$; $\mathrm{pH}, 4.5$; solvent, ethyl acetate; C4RAHA, $3 \mathrm{ml}, 1.08 \times 10^{-4} \mathrm{M} ; \lambda_{\max }, 341 \mathrm{~nm}$.

Table 4 Analysis of thorium(IV) in standard samples from the United States Geological Survey (USGS) and monazite sand

\begin{tabular}{lccr}
\hline \multirow{2}{*}{ Sample } & $\begin{array}{c}\text { Certified } \\
\text { value/ } \\
\mu \mathrm{g} \mathrm{ml}^{-1}\end{array}$ & \multicolumn{2}{c}{$\begin{array}{c}\text { Present method } \mathrm{d}^{\mathrm{b}} / \mu \mathrm{g} \mathrm{ml}^{-1} \\
\text { thorium(IV) found }\end{array}$} \\
\cline { 3 - 4 } & & Spectrophotometry & \multicolumn{1}{c}{ ICP-AES } \\
\hline BCR-1 (52/19) & 6.00 & $5.95 \pm 0.5$ & $5.985 \pm 0.016$ \\
WI & 2.42 & $2.50 \pm 0.08$ & $2.430 \pm 0.010$ \\
AGV-1 (74/19) & 24.20 & $24.15 \pm 0.05$ & $24.200 \pm 0.007$ \\
GSP-1 (17/22) & 104.00 & $105.1 \pm 0.05$ & $105.078 \pm 0.010$ \\
Soil-5 & 11.30 & $11.20 \pm 0.15$ & $11.298 \pm 0.005$ \\
Monazite sand ${ }^{\mathrm{a}}$ (\%) & - & $8.00 \pm 0.03$ & $8.00 \pm 0.005$ \\
Rare earth-silicon- & 0.196 & $0.20 \pm 0.01$ & $0.198 \pm 0.002$ \\
magnesium alloy- & & & \\
(88.8) & & & \\
Water sample 1 & - & $0.56 \pm 0.05$ & $0.515 \pm 0.003$ \\
& - & $0.09 \pm 0.03$ & $0.088 \pm 0.005$
\end{tabular}

a. The samples from Travancore, India.

b. The results are the average of ten determinations.

c. The samples are from Mumbai seawater.

gives an indication of the potential sensitivity of the proposed method. However, the selectivity of a reagent can be more realistically determined under condition where the extraction is carried out from a solution containing different metal ions. In order to examine this by the present method, the effect of various cations and anions in the separation and determination of thorium(IV) was studied. Interference studies were performed by measuring the absorbance of the extracted organic phase and the aqueous phase by ICP-AES. The tolerance limit was set as the amount of foreign ion causing a change of \pm 0.021 in absorbance, or a $2 \%$ error in the recovery of thorium(IV).

Thorium(IV) was extracted in the presence of a large number of competitive ions at the optimum $\mathrm{pH}$ of 4.5 ; none of them

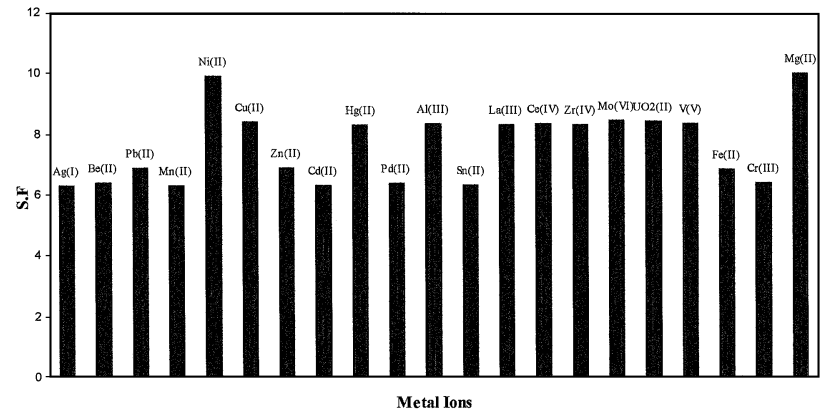

Fig. 9 Stability constants of thorium(IV) compared to other competitive metal ions.

affected the absorbance of the C4RAHA-thorium(IV) complex. The separation factor for thorium(IV) over these commonly associated metal ions $\left(\mathrm{M}^{\mathrm{n}+}\right)$ may be given by

$$
\mathrm{S} . \mathrm{F}=\frac{D_{\mathrm{Th}}}{D_{\mathrm{M}}},
$$

where $D_{\mathrm{Th}}$ and $D_{\mathrm{M}}$ are the distribution ratios of thorium $\left(\mathrm{ThO}^{2+}\right)$ and other metal $\left(\mathrm{M}^{\mathrm{n}+}\right)$ ions, respectively. As is evident from the Fig. 9 and Table 3, the proposed method has a high selectivity for thorium compared to other metal ions.

\section{Preconcentration of thorium}

The concentration of thorium(IV) in natural water samples is too low for its direct determination. Therefore, a preconcentration or enrichment step is necessary to bring the sample to the detectable limits of the existing instrumental method. The method was studied for the preconcentration of thorium(IV) in terms of its preconcentration factors.

$$
\mathrm{PF}=\frac{\text { Concentration of metal in organic phase }}{\text { Initial concentration of metal in aqueous phase }}
$$

A preconcentration study was carried out by extracting $20 \mu \mathrm{g}$ of thorium(IV) in $1000 \mathrm{ml}$ of the aqueous phase with $7.5 \mathrm{ml}$ of $0.005 \%$ C4RAHA in ethyl acetate. To evaluate the efficiency of preconcentration, expressed as recovery, the concentrations of thorium(IV) in the organic phase and the aqueous phase were determined by ICP-AES. A quantitative determination was possible with recovery up to $98 \%$ with a concentration factor of 133.

Determination of thorium(IV) in standard and natural samples Standard rock samples from the United States Geological Survey (USGS) were analyzed to test the reliability of the present method. The samples were digested in a mixture of perchloric acid and nitric acid, and evaporated to dryness. The residue was redissolved in $0.1 \mathrm{M}$ perchloric acid and diluted to $250 \mathrm{ml}$ with distilled water. An aliquot of the solution was taken for the extraction and determination of thorium(IV).

For the analysis of thorium(IV) in a rare earth siliconmagnesium alloy, a weight quantity of $0.1-0.2 \mathrm{~g}$ of a powder sample (rare earth silicon-magnesium alloy) was heated for 30 min in a dried platinum crucible. After it was cooled and 1-2 $\mathrm{ml}$ hydrofluoric acid was added, it was heated to dissolve and 2 $\mathrm{ml}$ of conc. $\mathrm{H}_{2} \mathrm{SO}_{4}$ was added. The contents were then heated to dryness, and the residue was dissolved in $5 \mathrm{ml}$ of $2 \mathrm{M} \mathrm{HCl}$. Finally, it was diluted to $100 \mathrm{ml}$ with distilled water and determined by ICP-AES. Matrix interferences were verified by 
comparing the slopes of the calibration graphs with those using the standard addition method. The results for the analysis of rocks, alloys, and seawater samples are given in Table 4.

\section{Conclusion}

The results obtained from the analysis of standard geological samples, monazite sand and seawater samples proved the reliability of the proposed method for their application to various samples. The proposed method is simple, specific, and sensitive for thorium(IV). Thorium(IV) is first preconcentrated by a liquid-liquid extraction technique, and then aspirated to ICP-AES with a detection limit of $3.3 \mathrm{ppb}$ and a quantification limit of $10.97 \mathrm{ppb}$ for thorium(IV) from a diverse matrix. Moreover, the molar absorptivity of $71201 \mathrm{~mol}^{-1} \mathrm{~cm}^{-1}$ achieved in the present method is high compared to most of the analogous methods cited in the literature.

\section{Acknowledgements}

The authors are thankful to UGC and DST, New Delhi for financial assistance. The authors are also thankful to CDRI, Lucknow and PRL, Ahmedabad for providing instrumental facilities.

\section{References}

1. J. L. Atwood, J. E. D. Davies, D. D. MacNicol, and F. Vögtle (ed.), "Comprehensive Supramolecular Chemistry", 1996, Elsevier Science, Oxford.

2. J. F. Stoddart, "In Frontiers in Supramolecular Organic Chemistry and Photochemistry", ed. H-J. Schneider and H. Dürr, 1991, Verlag Chimie, Weinheim.

3. A. G. S. Högberg, J. Org. Chem., 1980, 45, 4498.

4. B. A. Roberts, G. W. V. Cave, C. L. Raston, and J. L. Scott, Green Chem., 2001, 3, 280.

5. K. E. Peterson, R. C. Smith, and R. S. Mohan, Tetrahedron Lett., 2003, 44, 7723.

6. W. Sliwa, T. Zujewska, and B. Bachowska, Pol. J. Chem., 2003, 77, 1079 .

7. G. M. Martinez, C. R. Tetron, O. A. Tlapanco, A. Toscano, and R. Cruz-Almanza, Fullerene Sci. Technol., 2000, 8 , 475.

8. F. C. Tucci, A. R. Renslo, D. M. Rudkevich, and J. Rebek, Angew. Chem., Int. Ed. Engl., 2000, 39, 1076.

9. D. J. Eisler, C. W. Kirby, and R. J. Puddephatt, Inorg. Chem., 2003, 42, 7626.

10. B. Q. Ma and P. Coppens, Chem. Commun., 2003, 412.

11. K. Yonetake, T. Nakayama, and M. Ueda, J. Mater. Chem., 2001, 11, 761 .

12. O. Haba, K. Haga, M. Ueda, O. Morikawa, and H. Konishi, Chem. Mater., 1999, 11, 427.

13. O. Pietraszkiewicz, M. Kozbial, and M. Pietraszkiewicz, Pol. J. Chem., 1998, 72, 886.

14. K. Jchimura, E. Kurita, and M. Ueda, Eur. Pat., 1995, EP 671220

15. O. Pietraszkiewicz and M. Pietraszkiewicz, J. Inclusion Phenom. Macrocyclic Chem., 1999, 35, 261.

16. N. Yoshino, A. Satake, and Y. Kobuke, Angew. Chem., Int Ed. Engl., 2001, 40, 457.

17. E. Gaunert, H. Barnier, L. Nicod, A. Favre-Reguillon, J. Foos, A. Guy, C. Bardot, and M. Lemaire, Sep. Sci.
Technol., 1997, 32, 2309.

18. L. S. Kuznetsova, A. R. Mustafina, A. Y. Ziganshina, and E. K. Kazakova, J. Inclusion Phenom. Macrocyclic Chem., 2001, 40, 65 .

19. J. A. Dalziel and A. K. Slawinski, Talanta, 1972, 19, 1190.

20. T. Yamamoto, Anal. Chim. Acta, 1973, 65, 63.

21. H. H. Perkampus (translated by H. C. Grinter and T. L. Threlfall), "UV-VIS Spectroscopy and its Applications", 1982, Springer-Verlag, New York.

22. A. Suresh, S. Subramaniam, T. G. Srinivasan, and P. R. Vasudev Rao, Sol. Ext. Ion Exch., 1995, 13, 415.

23. S. Banerjee and S. Basu, J. Radioanal. Nucl. Chem., 2001, 250, 399.

24. M. L. P. Reddy and R. Meena, Radiochim. Acta, 2001, 89, 453.

25. P. G. Blanco, S. J. Arribas, and A. Sanz-Medel, Talanta, 1982, 29, 761.

26. C. Yonezawa and G. R. Choppin, J. Radioanal. Nucl. Chem., 1989, 233, 134.

27. K. Ohto, S. Inoue, N. Eguchi, T. Shinohara, and K. Inoue, Sep. Sci. Technol., 2002, 37, 1943.

28. J. Ramkumar, S. K. Nayak, and B. Maiti, J. Membr. Sci., 2002, 196, 203

29. Y. Fujikawa, M. Sugahara, E. Ikeda, and M. Fukui, J. Radioanal. Nucl. Chem., 2002, 252, 399.

30. G. W. Gokel (ed.), "Crown Ethers and Cryptands", 1991, The Royal Society of Chemistry, London.

31. Y. K. Agrawal, Rev. Anal. Chem., 1980, 3, 51.

32. Y. K. Agrawal and S. A. Patel, Rev. Anal. Chem., 1980, 4 , 237.

33. Y. K. Agrawal and R. K. Jain, Rev. Anal. Chem., 1982, 6, 49.

34. Y. K. Agrawal and M. Sanyal, Analyst, 1995, 120, 2759

35. K. S. Rao, D. Sarangi, P. Dash, and G. R. Chaudhury, J. Chem. Technol. Biotechnol., 2003, 78, 555.

36. K. R. Patel, S. K. Menon, and Y. K. Agrawal, Microchim. Acta, 1995, 125.

37. S. Singh, S. Singh, H. Sharma, and L. Sharma, Ind. J. Chem., 1994, 34B, 428.

38. N. Demirel, M. Merdivan, N. Pirinccioglu, and C. Hamamci, Anal. Chim. Acta, 2003, 1, 213.

39. R. N. John, C. L. Argell, T. Ito, and R. J. O. Smith, Can. J. Chem., 1959, 37, 2009.

40. N. B. Colthup, L. H. Dall, and S. E. Wiberely, "Introduction to Infrared and Raman Spectroscopy", 3rd ed., 1980, Academic Press, Boston.

41. A. D. Cross, "An Introduction to Practical Infrared Spectroscopy", 2nd ed., 1964, Butterworths, London.

42. J. C. D. Brand and G. Eglinton, "Application of Spectroscopy to Organic Chemistry", 1965, Old Bourne Press, London, 145 - 143.

43. Y. K. Agrawal and S. G. Tandon, J. Chem. Eng. Data, 1977, 22, 70 .

44. Y. K. Agrawal and A. J. Mudaliar, J. Chem. Eng. Data, 1979, 24, 246.

45. Y. K. Agrawal and R. K. Jain, J. Chem. Eng. Data, 1979, 24, 250.

46. L. Bennouna, J. Vicens, Z. Asfari, A. Yahyaoui, and M. Burgard, J. Inclusion Phenom. Macrocyclic Chem., 2001, 40,95 .

47. L. H. J. Lajunen, "Spectrochemical Analysis by Atomic Absorption and Emission", 1992, Royal Society of Chemistry, Cambridge, 9.

48. H. Kondo, M. Nishida, and I. Yoshida, Anal. Sci., 2002, 18, 113. 